\title{
Analysis of redox regulation of cytochrome c-induced apoptosis in a cell-free system
}

\author{
Zhaohui Pan ${ }^{1}$, David W. Voehringer ${ }^{1}$ and \\ Raymond E. Meyn ${ }^{\star, 1}$ \\ 1 Department of Experimental Radiation Oncology, Box 66, University of Texas \\ MD Anderson Cancer Center, 1515 Holcombe Blvd., Houston, Texas 77030, \\ USA \\ * corresponding author: Dr. Raymond E. Meyn \\ tel: 713-792-3424; fax: 713-794-5369; e-mail: rmeyn@notes.mdacc.tmc.edu
}

Received 25.2.98; revised 22.1.99; accepted 19.5.99

Edited by M. Noble

\begin{abstract}
In this study, we investigated the importance of redox and Bcl2 status on cytochrome c-mediated apoptosis. Two mouse lymphoma cell lines, LYas and LYar that express Bcl-2 protein at different levels, were used to reconstitute a cell-free system. Cytoplasmic extracts made from apoptosis-sensitive LYas cells $2.5 \mathrm{~h}$ after exposure to $5 \mathrm{~Gy} \gamma$-radiation were able to induce apoptosis in isolated nuclei, whereas extracts made from LYas cells at time points earlier than $2.5 \mathrm{~h}$, or from Bcl-2overexpressing, apoptosis-resistant LYar cells at all time points after irradiation were inactive. Apoptotic activity was restored to inactive extracts by the addition of oxidized but not reduced cytochrome $\mathrm{c}$. Cytochrome $\mathrm{c}$ reductase was able to inhibit apoptosis in extracts made from LYas cells $2.5 \mathrm{~h}$ after irradiation and $L Y$ ar extracts activated by addition of oxidized cytochrome c. Antioxidants, but not oxidant defensive enzymes, blocked apoptosis implying that antioxidants might alter the redox state of factors important in mediating apoptosis. These findings confirm the importance of cellular redox state during apoptosis and are consistent with a role for $\mathrm{Bcl}-2$ in regulating this redox state.
\end{abstract}

Keywords: Apoptosis; cytochrome c; cell-free system; redox; radiation

Abbreviations: $A B$, ascorbate; GSH, glutathione; L-cys, Lcysteine; NAC, n-acetyl cysteine; PARP, poly-ADP ribose polymerase; PBS, phosphate buffered saline; PT, mitochondrial membrane permeability transition

\section{Introduction}

We previously reported on the relationship between the antiapoptotic protein $\mathrm{Bcl}-2$ and the antioxidant glutathione (GSH). ${ }^{1,2}$ Total GSH levels were increased in most cell systems under conditions where $\mathrm{Bcl}-2$ protein was overexpressed, whereas, in all systems studied, GSH was redistributed to the nucleus compared to non-Bcl-2-expres- sing cells. These observations have led us to suggest that $\mathrm{Bcl}-$ 2 regulates apoptosis sensitivity through modulation of cellular redox, primarily at the level of the nucleus and possibly at other sites as well. ${ }^{1,3}$ The $\mathrm{Bcl}-2$ protein, which is located to varying degrees in the nuclear membrane, outer mitochondrial membrane, and the endoplasmic reticulum, prevents apoptosis when overexpressed in a variety of cell types. ${ }^{4}$ One of the many functions ascribed to $\mathrm{Bcl}-2$ has been an endogenous inhibitory activity of mitochondrial membrane permeability transition (PT). In a series of recent papers, inhibition of PT by Bcl-2 has been linked to the blocked release of apoptogenic factors from mitochondria. ${ }^{5-7}$ One of these factors, cytochrome $\mathrm{c}$, released from mitochondria during this process, appears to be able to activate caspases in vitro and is involved in one of the effector pathways that initiate nuclear apoptosis. ${ }^{8}$ Cytochrome c, which is located on the outside of the inner mitochondrial membrane and involved in electron transport, was found to be required for activation of caspase 3 and nuclear fragmentation in cell-free extracts. ${ }^{8}$ Whereas the release of cytochrome $\mathrm{c}$ from mitochondria is blocked in Bcl-2 transfected cells treated with anticancer drugs, ${ }^{6}$ recent reports have identified an additional role for Bcl-2 downstream of cytochrome c. ${ }^{9,10}$ In these papers, it was shown that apoptosis induction by exogenous or endogenous release of cytochrome $c$ into the cytosol of intact cells could be blocked by the expression of $\mathrm{Bcl}-2$ even though free cytochrome $\mathrm{c}$ was detectable in the cytosol. Additionally, using a cell-free system, we have previously reported that caspase 3 and endonuclease activity initiated by granzyme B could be suppressed by the addition of GSH to the incubation medium. ${ }^{3}$ This suggested to us that one of the ways $\mathrm{Bcl}-2$ regulates apoptosis involves the modulation of GSH and its subsequent inhibition of apoptotic factors.

In the present study, we used a cell-free system to investigate the importance of cytochrome $\mathrm{c}$ redox state on activating nuclear apoptosis. Extracts from two mouse lymphoma cell lines with different sensitivities to $\gamma$-radiation and different levels of Bcl-2 expression, LYas (sensitive $\left.\left(\mathrm{Bcl}-2^{-}\right)\right)$and LYar (resistant $\left.\left(\mathrm{Bcl}-2^{+}\right)\right)$cells, were utilized. The redox state of cytochrome $\mathrm{c}$ was found to be critical for the induction of nuclear changes associated with apoptosis and this activity was suppressed in the presence of antioxidants.

\section{Results}

Induction of apoptosis using cell-free extracts made from irradiated LYas cells

Two mouse lymphoma cell lines were used to study the mechanism of cytochrome c-induced apoptosis. In radiationsensitive LYas cells, which do not express Bcl-2, DNA fragmentation becomes detectable above control levels $2.5 \mathrm{~h}$ after irradiation. They undergo $80 \%$ DNA fragmentation 
by $4 \mathrm{~h}$ after 5 Gy radiation, whereas radiation-resistant LYar cells, which express Bcl-2, show only $10 \%$ DNA fragmentation under the same conditions. ${ }^{11}$ One of the nuclear proteins targeted for destruction during apoptosis is the $116 \mathrm{kD}$ nuclear enzyme PARP, which is a substrate for caspase $3^{12}$ Consistent with the established time for appearance of DNA fragmentation, PARP cleavage was detected by $2.5 \mathrm{~h}$ after irradiation in LYas cells, but there was no detectable cleavage of PARP $3 \mathrm{~h}$ after irradiation in LYar cells as demonstrated by immunoblot analysis (Figure 1A). In an attempt to determine when the apoptotic changes in the cytoplasm of these cells occurs, cytosolic extracts were made at different times after irradiation. Figure $1 \mathrm{~B}$ shows the percentage DNA fragmentation in nuclei after incubation with cell-free extracts made from irradiated and unirradiated LYar and LYas cells at different times after irradiation. Extracts made from LYas cells at $2.5 \mathrm{~h}$ exhibited high apoptotic activity (Figure 1B). Extracts made from unirradiated LYas cells or made $1 \mathrm{~h}$ after irradiation did not display apoptotic activity. In addition, there was no apoptotic activity in extracts made from LYar cells up to $2.5 \mathrm{~h}$ after irradiation. The source of the nuclei, LYas or LYar, did not make any difference (Figure 1C).

\section{Effect of cytochrome c on apoptotic activity of cell-free extracts}

It has been reported that cytochrome $\mathrm{c}$ is capable of initiating apoptosis in cell-free extracts from HeLa cells. ${ }^{8}$ However, that report did not establish which form of cytochrome $\mathrm{c}$, oxidized (ferri) or reduced (ferro), had this potential. Cytosolic extracts made from both unirradiated and irradiated LYas and LYar cells were able to induce apoptotic changes on the addition of ferricytochrome $\mathrm{c}$ (Sigma) at a concentration of $1.6 \mu \mathrm{M}$ (Figure 2A). The induction of apoptosis under these conditions was dependent on the concentration of ferricytochrome c (data not shown).

To estimate the levels of cytochrome c released from mitochondria into cell-free extracts in irradiated cells, extracts were sequentially filtered through $0.2 \mu \mathrm{m}, 0.1 \mu \mathrm{m}$ ultrafree-MC (Millipore), and microcon-100 (Amicon) centrifugal filters to remove contaminating mitochondria from

A

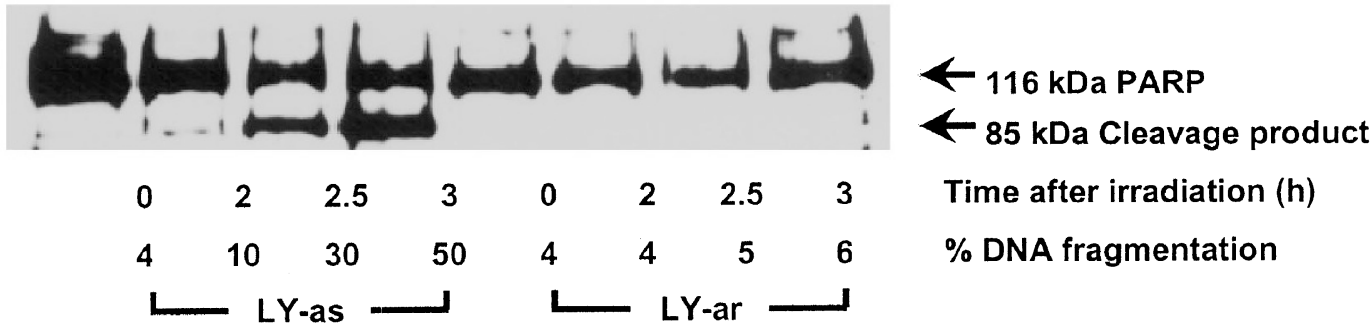

B
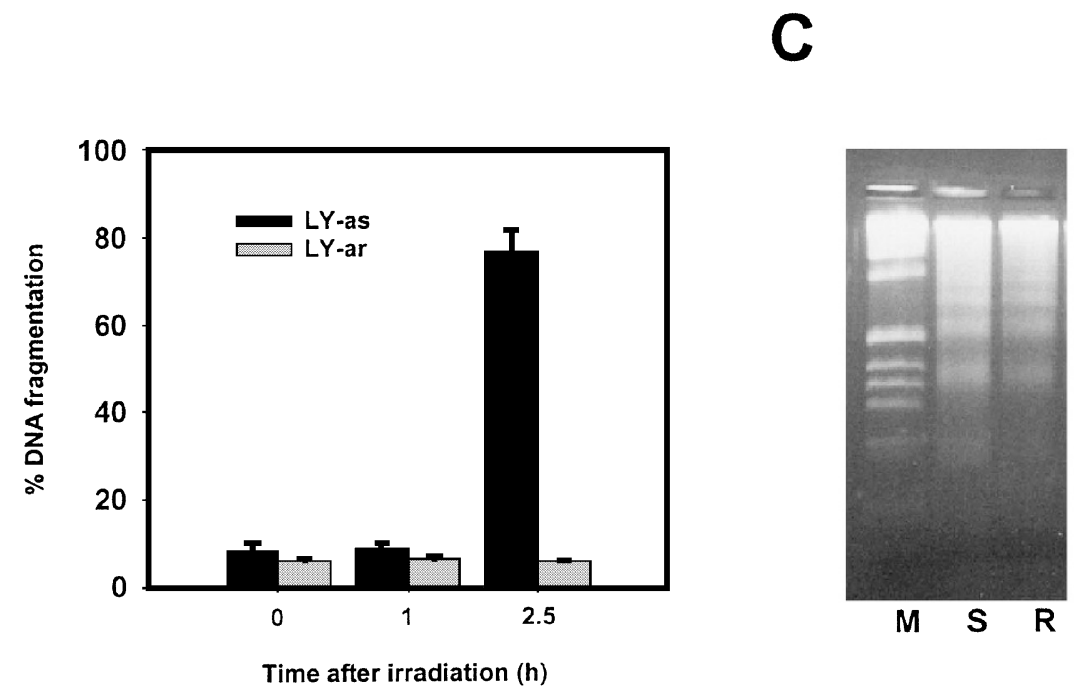

Figure 1 Kinetics of $\gamma$-radiation-induced apoptosis in LYas and LYar cells and activation of cell-free extracts. LYas and LYar cells were exposed to 5 Gy $\gamma$ radiation using a ${ }^{137} \mathrm{Cs}$ source. (A) Immunoblot analysis of PARP cleavage and percentage of DNA fragmentation at different times after irradiation. Position of 116-kDa PARP and its $85-\mathrm{kDa}$ cleavage product are indicated by arrows. (B) LYar nuclear apoptosis in cell-free extracts made from LYar and LYas cells at the indicated times after 5 Gy radiation. Error bars are representative of the standard deviation. (C) LYar (R) and LYas (S) nuclear apoptosis in extract made from LYas cells $2.5 \mathrm{~h}$ after irradiation. Molecular weight markers (M) are also shown 
the cytosol and then analyzed on immunoblots. Following irradiation, there was a detectable increase above control levels of released cytochrome $c$ in extracts made from LYas cells that was not observed in extracts made from LYar cells (Figure 2B).

In contrast to ferricytochrome c, ferrocytochrome c (Sigma) had no effect on the apoptotic activity in extracts made from LYar cells $2.5 \mathrm{~h}$ after irradiation (Figure $2 \mathrm{C}$ ). Moreover, the addition of ferricytochrome $c$ reductase suppressed apoptosis of nuclei in extracts made from LYas cells $2.5 \mathrm{~h}$ after irradiation (Figure 2D) and totally blocked apoptosis in extracts made from LYar cells $2.5 \mathrm{~h}$ after irradiation when ferricytochrome $\mathrm{c}$ had been added to induce apoptosis (Figure 2C).

\section{Effects of antioxidants and oxidant defensive enzymes on apoptosis in cell-free extracts}

Since, as described above, the redox state of cytochrome c was critical in initiating apoptosis and we have previously shown that $\mathrm{Bcl}-2$ regulates $\mathrm{GSH}$ localization, we tested whether GSH and other antioxidants could block cytochrome c mediated apoptosis in cell-free extracts. Various oxidant defensive enzymes, i.e. GSH-peroxidase, GSH-reductase, superoxide dismutase, and catalase, were included in this analysis to assess the possible involvement of reactive oxygen species. GSH (Sigma), L-cysteine (L-Cys) (Gibco), $\mathrm{N}$-acetyl-cysteine (NAC) (Sigma), and ascorbic acid (AB) (Sigma) were tested in extracts made from LYas and LYar cells $2.5 \mathrm{~h}$ after irradiation. Ferricytochrome c, $0.5 \mu \mathrm{g}$, was added to $35 \mu \mathrm{g}$ of the LYar extracts as an apoptosis initiator. All the antioxidants were capable of blocking DNA fragmentation at a concentration of $5 \mathrm{mM}$ (Figure 3). In contrast, apoptosis was not blocked by any of the antioxidant defensive enzymes tested at a concentration of $10 \mathrm{U} / \mathrm{ml}$.

\section{Discussion}

In this study, we used a cell-free system to investigate the importance of cytochrome $\mathrm{c}$ redox state on the regulation of $\gamma$ radiation-induced apoptosis. Our observations show that the development of apoptotic activity in cell-free extracts
A

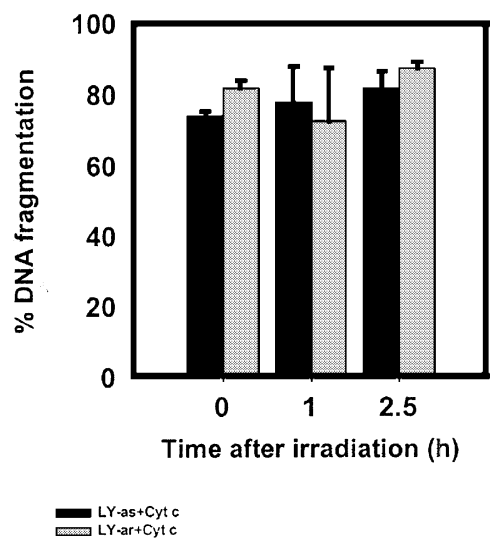

C

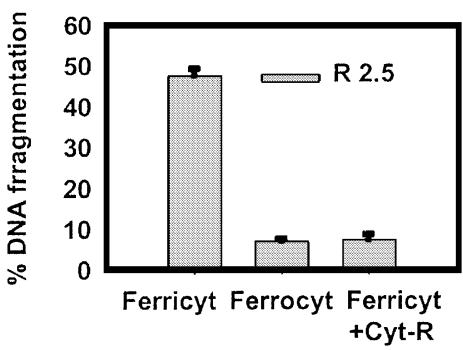

B

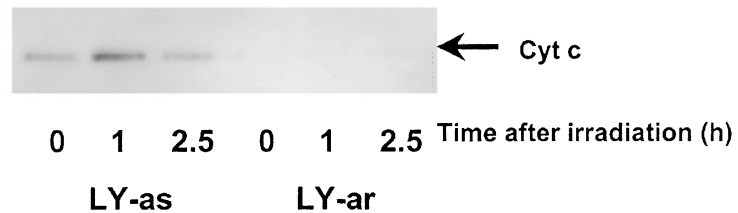

D

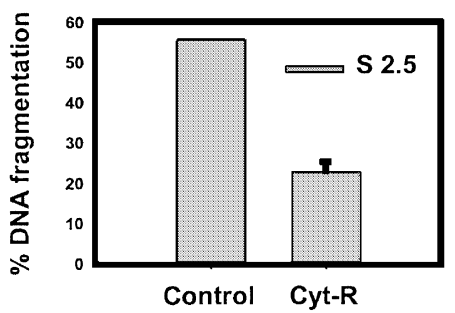

Figure 2 Effects of ferricytochrome c, ferrocytochrome $c$, and ferricytochrome $c$ reductase on LYar nuclear fragmentation in cell-free extracts made from irradiated LYas and LYar cells at different post-radiation times. (A) $35 \mu \mathrm{g}$ of cell-free extracts were incubated with $0.5 \mu \mathrm{g}$ of ferricytochrome $\mathrm{c}$ and $2 \times 10^{5}$ radiolabeled LYar nuclei at $25^{\circ} \mathrm{C}$ for $90 \mathrm{~min}$ in a final volume of $10 \mu \mathrm{l}$. (B) Cell-free extracts were used for immunoblot analysis of cytochrome $\mathrm{C}$. Extracts were filtered through $0.2 \mu \mathrm{m}, 0.1 \mu \mathrm{m}$ ultrafree-MC and microcon-100 centrifugal filters. Equal amounts of protein were loaded in each well. (C) $35 \mu \mathrm{g}$ of cell-free extracts made from LYar cells $2.5 \mathrm{~h}$ (R2.5) after irradiation ( $5 \mathrm{~Gy}$ ) were incubated with $0.5 \mu \mathrm{g}$ of ferricytochrome $\mathrm{c}, 1.5 \mu \mathrm{g}$ of ferrocytochrome $\mathrm{c}$, or a mixture of $0.5 \mu \mathrm{g}$ of ferricytochrome $\mathrm{c}$ and $10 \mathrm{U} / \mathrm{ml}$ of ferricytochrome $\mathrm{c}$ reductase. They were then preincubated at $25^{\circ} \mathrm{C}$ for 5 min. Radiolabeled LYar nuclei were added and incubated at $25^{\circ} \mathrm{C}$ for $90 \mathrm{~min}$. (D) Ferricytochrome c reductase was preincubated with cell-free extracts made from LYas cells $2.5 \mathrm{~h}(\mathrm{~S} 2.5)$ after irradiation at $25^{\circ} \mathrm{C}$ for 5 min and then incubated with LYar nuclei at $25^{\circ} \mathrm{C}$ for $90 \mathrm{~min}$. Error bars are representative of the standard deviation 


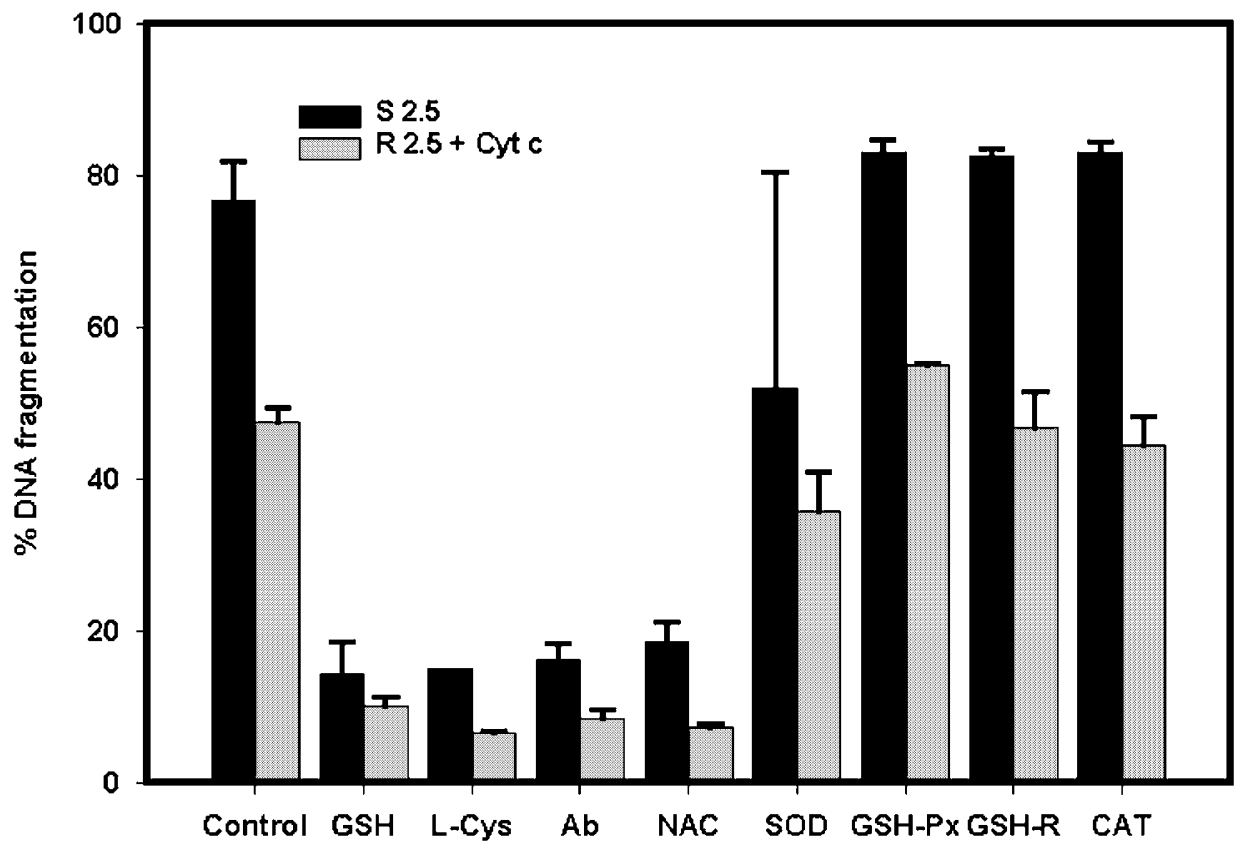

Figure 3 Effects of antioxidants and oxidant defense enzymes on LYar nuclear fragmentation in apoptotically active cell-free extracts. $35 \mu \mathrm{g}$ of cell-free extracts made from LYas (S 2.5) and LYar (R 2.5) cells $2.5 \mathrm{~h}$ after irradiation ( $5 \mathrm{~Gy}$ ) were incubated with glutathione (GSH, $5 \mathrm{mM}$ ), L-cysteine (L-Cys, $5 \mathrm{mM}$ ), ascorbate (Ab, $5 \mathrm{mM}$ ), $\mathrm{N}$-acetyl-cysteine (NAC, $5 \mathrm{mM})$, superoxide dismutase (SOD, $10 \mathrm{U} / \mathrm{ml})$, glutathione peroxidase (GSH-Px, $10 \mathrm{U} / \mathrm{ml})$, glutathione reductase (GSH-R, $10 \mathrm{U} / \mathrm{ml})$, catalase $(\mathrm{CAT}, 10 \mathrm{U} / \mathrm{ml})$, and $2 \times 10^{5}$ of radiolabeled LYar nuclei at $25^{\circ} \mathrm{C}$ for $90 \mathrm{~min} .0 .5 \mu \mathrm{g}$ ferricytochrome $\mathrm{C}$ was added to the extracts from $\mathrm{LY}$ ar cells as an initiator of apoptosis. Error bars are representative of the standard deviation

corresponds to the release of apoptotic factors into the cytosol and activation of caspases. At $2.5 \mathrm{~h}$ after irradiation, intact LYas cells began to undergo cell death as shown by DNA fragmentation and by immunoblot analysis of PARP cleavage (Figure 1A). Cell-free extracts made from LYas cells $2.5 \mathrm{~h}$ after irradiation contained factors that were capable of inducing DNA fragmentation in isolated nuclei. Apoptotic factors were not activated in LYas cells before $2 \mathrm{~h}$ after irradiation attesting to the time dependence of apoptotic inducing ability in this system.

It has been reported that cytochrome $c$ released from mitochondria is required to activate caspase 3 and induce nuclear fragmentation in a dATP-containing cell-free system. ${ }^{8}$ Cytochrome $c$ has two different forms, the oxidized form (ferricytochrome c) and the reduced form (ferrocytochrome $\mathrm{c}$ ). We found that $0.5 \mu \mathrm{g}$ of ferricytochrome c was sufficient to activate cell-free extracts made from both LYar and LYas cells (Figure 2A). This suggests that the intact cell death effector pathway in both cell lines can be triggered by an excess of the oxidized form of cytochrome c. Immunoblot analysis showed that there was only a small increase in the level of cytochrome $\mathrm{c}$ in $0.1 \mu \mathrm{m}$ filtered LYas extracts made at different times after irradiation. The redox state of this naturally released cytochrome c could not be determined but an excess of reduced cytochrome $c$ was inactive in this system (Figure 2C) consistent with a requirement of the oxidized form for activating apoptosis.

Additionally, ferricytochrome c reductase was able to inhibit nuclear apoptosis in extracts made from LYas cells
$2.5 \mathrm{~h}$ after irradiation (Figure 2D) and totally blocked ferricytochrome c-induced apoptosis (Figure 2C), further suggesting that the downstream apoptotic processes depended on the redox state of iron in the heme group of cytochrome c. Kluck and colleagues reported that the redox state of the heme iron in cytochrome $c$ was not critical for its pro-apoptotic activity, as suggested by experiments using $\mathrm{Cu}$ - and $\mathrm{Zn}$-substituted cytochrome $\mathrm{c}$ derivatives. ${ }^{13}$ However, these derivatives may have different biological functions from naturally occurring ferri and ferrous cytochrome c. The addition of exogenous oxidized cytochrome $c$ activated cell free extracts independently of irradiation or time of addition (Figure 2A). This may indicate that excess cytochrome $\mathrm{c}$ is able to overcome the necessity of additional factors required under physiological conditions ${ }^{14}$ where the cytosol becomes active over time (Figure 1B).

The fact that no cytochrome $\mathrm{c}$ was detected in the LYar cells (Figure $2 \mathrm{~B}$ ) is consistent with reports that the release of cytochrome $\mathrm{C}$ from mitochondria is blocked in $\mathrm{Bcl}-2-$ expressing cells. ${ }^{5,6}$ Such results have clearly indicated the importance of $\mathrm{Bcl}-2$ localized at the level of mitochondria membranes. ${ }^{15}$ However, $\mathrm{Bcl}-2$ is also located in other membranes including the endoplasmic reticulum and nuclear envelope. ${ }^{16}$ Thus, Bcl-2 may also act downstream of mitochondrial cytochrome c release as suggested by the fact that apoptosis is blocked in Bcl-2-expressing cells even when cytochrome $\mathrm{c}$ is microinjected into them. ${ }^{17}$

One mechanism to explain this effect relates to a previous report that defined a role for Bcl-2 in the cell's 
antioxidant pathways. ${ }^{18}$ We and others have shown that one such pathway may involve the antioxidant GSH because $\mathrm{Bcl}$-2-expressing cells have higher intracellular levels of $\mathrm{GSH}^{2,19}$ The results reported here confirm the importance of antioxidants such as GSH as regulators of apoptosis. Although none of the oxidant defense enzymes appeared to have any effect on radiation- or radiation plus cytochrome c-induced apoptosis, antioxidants including GSH reversed the apoptotic process in cell-free extracts made from irradiated cells undergoing apoptosis and in extracts with cytochrome $\mathrm{c}$ as the apoptosis initiator (Figure 3). This suggests that antioxidants might alter the redox state of factors essential in apoptosis rather than quenching free radicals or reactive oxygen species putatively generated during apoptosis. A recent report from our laboratory indicates that nuclear caspases represent at least one redox-sensitive target whose activity can be modulated by $\mathrm{GSH}^{3}$

GSH is the most abundant intracellular thiol and regulates the redox state of many other cellular substances. The data presented here support the hypothesis that $\mathrm{Bcl}-2$ regulates intracellular $\mathrm{GSH}$ levels and thereby modulates apoptosis through the redox state of cytochrome $\mathrm{c}$ and/or other apoptotic factors. The mechanism by which Bcl-2 modulates GSH metabolism is not known but LYar cells have nearly twice the GSH content of LYas cells. This effect could not be explained on the basis of an enhanced rate of GSH synthesis because agents that deplete GSH through conjugation reversed Bcl-2's inhibition of apoptosis whereas inhibitors of GSH synthesis did not. ${ }^{2}$ In a more recent examination of this question, we demonstrated that $\mathrm{Bcl}-2$ directs the redistribution of $\mathrm{GSH}$ into the nucleus of the cell where it inhibits the activity of nuclear caspases. ${ }^{3}$ However, we have no reason to believe that Bcl-2's ability to modulate GSH metabolism is limited to the nucleus. The results reported here utilizing cell-free systems would also be consistent with a Bcl-2-mediated role for $\mathrm{GSH}$ in the regulation of other redox sensitive factors or reactions required for apoptosis at the level of mitochondria or in the cytosol.

\section{Materials and Methods}

\section{Preparation of cell-free extracts}

The mouse lymphoma cells lines LYas and LYar were cultured in RPMI 1640 medium supplemented with $10 \%$ fetal bovine serum, $100 \mathrm{U} / \mu \mathrm{l}$ penicillin, $100 \mathrm{mg} / \mathrm{ml}$ streptomycin sulfate, and $2 \mathrm{mM}$ glutamine at $37^{\circ} \mathrm{C}$ in a $5 \% \mathrm{CO}_{2}$ incubator. Following different treatments, cells $\left(1 \times 10^{6} / \mathrm{ml}\right)$ were washed once with phosphate-buffered saline (PBS) and resuspended in five volumes of extraction buffer containing $10 \mathrm{mM}$ PIPES, (pH 7.4), $2 \mathrm{mM} \mathrm{MgCl}, 1 \mu \mathrm{g} / \mathrm{ml}$ aprotinin, $1 \mu \mathrm{g} / \mathrm{ml}$ pepstatin, $1 \mu \mathrm{g} / \mathrm{ml}$ leupeptin, $0.1 \mathrm{mM}$ phenylmethylsulfonyl fluoride, and $1 \mathrm{mM}$ dithiothreitol. Cells were disrupted in a Dounce homogenizer by 20 strokes with a B pestle. Cell lysates were transferred into $1.5 \mathrm{ml}$ microcentrifuge tubes, and the nuclei were pelleted at $200 \times g$ for $5 \mathrm{~min}$. The decanted cytosol was further clarified by centrifugation at $16000 \times g$ for $30 \mathrm{~min}$. The cleared cytosol was carefully removed, aliquoted, and stored at $-80^{\circ} \mathrm{C}$. In some experiments, the extracts were further spun through $0.2-\mu \mathrm{m}, 0.1-\mu \mathrm{m}$ ultrafree-MC (Millipore), and microcon-100 (Amicon) centrifugal filters.

\section{Preparation of nuclei}

The LYas and LYar cells were labeled with $\left[2-{ }^{14} \mathrm{C}\right]$-thymidine (Amersham) at a concentration of $10 \mathrm{nCi} / \mathrm{ml}$ for one cell cycle $(12 \mathrm{~h})$ and then collected by centrifugation at $200 \times g$ for $5 \mathrm{~min}$. Cells were washed once with PBS and resuspended in extraction buffer. After incubation on ice for $15 \mathrm{~min}$, cells were disrupted by 20 strokes with a Dounce homogenizer. Nuclei were pelleted by centrifugation at $200 \times g$ for $5 \mathrm{~min}$ and washed three times with extraction buffer. The washed nuclei were resuspended in nuclear storage buffer (extraction buffer with $50 \%$ glycerol) at $2 \times 10^{8}$ nuclei/ml and then stored in $20-\mu \mathrm{l}$ aliquots at $-80^{\circ} \mathrm{C}$. Before use, thawed nuclei were washed once with $200 \mu \mathrm{l}$ of extraction buffer and then resuspended in $20 \mathrm{ml}$ of extraction buffer.

\section{Reconstitution of the cell-free extract and quantitation of apoptosis}

Reaction mixtures contained $9 \mu \mathrm{l}$ of cell-free extract, $1 \mu \mathrm{l}$ of radiolabeled nuclei $\left(2 \times 10^{5}\right)$, and $1 \mu$ l of extraction buffer. The mixtures were incubated at room temperature in the presence of $2 \mathrm{mM}$ ATP, $10 \mathrm{mM}$ creatine phosphate, and $30 \mu \mathrm{g} / \mathrm{ml}$ phosphocreatine kinase for $90 \mathrm{~min}$ to generate ATP. The method used for measurement of DNA fragmentation is a modification of one described previously. ${ }^{20}$ In brief, the nuclei were lysed with $300 \mu$ l of lysis buffer (10 mM Tris$\mathrm{HCl}, \mathrm{pH} 7.5 / 1 \mathrm{mM}$ EDTA/0.2\% Triton X-100). The chromatin was pelleted by centrifugation at $14000 \times g$ for $10 \mathrm{~min}$. The supernatants, which contained DNA, were removed to a liquid scintillation vial containing $3 \mathrm{ml}$ Liquifluor $^{\mathrm{TM}}$ cocktail (Packard) with $50 \mathrm{mM}$ glacial acetic acid, and disintegrations counted by a liquid scintillation counter (Packard). The chromatin pellets were solubilized in $300 \mathrm{ml}$ of Soluene $^{\mathrm{TM}}$ (Packard), and disintegrations counted. DNA fragmentation was expressed as the percentage of radioactivity found in the supernatant fraction compared to the total radioactivity (pellets plus supernatants).

In some experiments, DNA degradation was visualized by electrophoresis. After incubation with cell-free extracts, nuclei were lysed with $100 \mu$ l of buffer B (100 mM Tris- $\mathrm{HCl}, \mathrm{pH} 8.5 / 5 \mathrm{mM}$ EDTA/ $0.2 \% \mathrm{SDS} / 0.2 \mathrm{M} \mathrm{NaCl} / 0.2 \mathrm{mg} / \mathrm{ml}$ protease $\mathrm{K}$ ) and incubated overnight at $37^{\circ} \mathrm{C}$. DNA was precipitated by adding $\mathrm{NaCl}$ at a final concentration of $1.5 \mathrm{~N}$ and an equal volume of isopropanol. DNA pellets were washed with $70 \%$ ethanol and dissolved in $10 \mu \mathrm{l}$ of buffer $\mathrm{C}(19 \mathrm{mM}$ Tris- $\mathrm{HCl}, \mathrm{pH}$ 7.5/1 mM EDTA/0.2 mg/ml DNase-free RNase A). After incubation at $37^{\circ} \mathrm{C}$ for $2 \mathrm{~h}$, the DNA was analyzed by gel electrophoresis using $2 \%$ agarose gel in the presence of $1 \mu \mathrm{g}$ of ethidium bromide per lane.

\section{Electrophoresis and immunoblot analysis}

A monoclonal antibody against rat cytochrome c (7H8.2C12) was purchased from Pharmingen, and a monoclonal antibody against poly (ADP-ribose) polymerase (PARP, C2-10) was obtained from Enzyme System Products. Protein concentrations of cell-free extracts were estimated using Coomassie ${ }^{R}$ protein assay reagent from Pierce. Equal amounts of total protein per lane were separated by $5 \% / 15 \%$ SDSpolyacrylamide gel electrophoresis followed by transfer to a polyvinylidene difluoride membrane using the standard procedure of the manufacturer. A radiograph of the immunoblot was visualized after incubation in horseradish peroxidase-conjugated anti-mouse immunoglobulin $G$ and Supersignal substrate Western blotting detection reagent (Pierce). Quantification was performed by scanning laser densitometery. 


\section{Acknowledgements}

The authors wish to thank Ms Marvette Hobbs for expert technical assistance. This work was supported for NIH grants CA 69003, CA 06294 and the institutional core grant CA 16672 from the National Cancer Institute.

\section{References}

1. Voehringer DW and Meyn RE (1998) Reversing drug resistance in Bcl-2expressing tumor cells by depleting glutathione. Drug Resist. Updates 1:345351

2. Mirkovic N, Voehringer DW, Story MD, McConkey DJ, McDonnell TJ and Meyn $\mathrm{RE}$ (1997) Resistance to radiation-induced apoptosis in Bcl-2-expressing cells is reversed by depleting cellular thiols. Oncogene 15: 1461-1470

3. Voehringer DW, McConkey DJ, McDonnell TJ, Brisbay S and Meyn RE (1998b) $\mathrm{Bcl}-2$ expression causes redistribution of glutathione to the nucleus. Proc. Natl. Acad. Sci. USA 95: 2956-2960

4. Reed JC (1994) Bcl-2 and the regulation of programmed cell death. J. Cell Biol. 124: $1-6$

5. Kluck RM, Bossy-Wetzel E, Green DR and Newmeyer DD (1997) The release of cytochrome c from mitochondria: a primary site for $\mathrm{Bcl}-2$ regulation of apoptosis. Science 275: 1132-1136

6. Yang J, Liu X, Bhalla K, Kim CN, Ibrado AM, Cai J, Peng TI, Jones DP and Wang X (1997) Prevention of apoptosis by Bcl-2: release of cytochrome $\mathrm{C}$ from mitochondria blocked. Science 275: 1129-1132

7. Susin SA, Zamzami N, Castedo M, Hirsch T, Marchetti P, Macho A, Daugas E, Geuskens M and Kroemer G (1996) Bcl-2 inhibits the mitochondrial release of an apoptogenic protease. J. Exp. Med. 184: 1331-1341

8. Liu XS, Kim CN, Yang J, Jemmerson R and Wang XD (1996) Induction of apoptotic program in cell-free extracts - requirement for dATP and cytochrome $c$. Cell 86: 147-157

9. Rossé T, Olivier R, Monney L, Rager M, Conus S, Fellay I, Jansen B and Borner C (1998) Bcl-2 prolongs cell survival after Bax-induced release of cytochrome C. Nature 391: 496-509
10. Zhivotovsky B, Orrenius S, Brustugun OT and Døskeland SO (1998) Injected cytochrome $c$ induces apoptosis. Nature 391: 449-450

11. Story MD, Voehringer DW, Malone CG, Hobbs ML and Meyn RE (1994) Radiation-induced apoptosis in sensitive and resistant cells isolated from a mouse lymphoma. Int. J. Radiat. Biol. 66: 659-668

12. Kaufmann SH, Desnoyers S, Ottaviano Y, Davidson NE and Poirier GG (1993) Specific proteolytic cleavage of poly(ADP-ribose) polymerase: an early marker of chemotherapy-induced apoptosis. Cancer Res. 53: 3976-3985

13. Kluck RM, Martin SJ, Hoffman BM, Zhou JS, Green DR and Newmeyer DD (1997) Cytochrome c activation of CPP32-like proteolysis plays a critical role in a Xenopus cell-free apoptosis system. EMBO J. 16: 4639-4649

14. Li P, Nijhawan D, Budihardjo I, Srinivasula SM, Ahmad M, Alnemri ES and Wang XD (1997) Cytochrome $c$ and dATP-dependent formation of Apaf-1caspase-9 complex initiates an apoptotic protease cascade. Cell 91: 479-489

15. Zamzami N, BrennerC, Marzo I, Susin SA and Kroemer G (1998) Subcellular and submitochondrial mode of action of Bcl-2-like oncoproteins. Oncogene 20: $2265-2282$

16. Krajewski S, Tanaka S, TakayamaS, Schibler MJ, Fenton W and Reed JC (1993) Investigation of the subcellular distribution of the Bcl-2 oncoprotein: residence in the nuclear envelope, endoplasmic reticulum, and outer mitochondrial membranes. Cancer Res. 53: 4701-4714

17. Brustugun OT, Fladmark KE, Døskeland SO, Orrenius $S$ and Zhivotovsky $B$ (1998) Apoptosis induced by microinjection of cytochrome $C$ is caspasedependent and is inhibited by Bcl-2. Cell Death Differ. 5: 660-668

18. Hockenbery DM, Oltvai ZN, Yin XM, Milliman CL and Korsmeyer SJ (1993) Bcl-2 functions in an antioxidant pathway to prevent apoptosis. Cell 75: 241-251

19. Kane DJ, Sarafin TA, Auton S, Hahn H, Gralla FB, Valentine JC, Ord T and Bredesen DE (1993) Bcl-2 inhibition of neural cell death: decreased generation of reactive oxygen species. Science 262: 1274-1276

20. Story MD, Voehringer DW, Stephens LC and Meyn RE (1993) L-asparaginase kills lymphoma cells by apoptosis. Cancer Chemother. Pharmacol. 32: 129-133 